\title{
Uma Análise da Proposta de Déficit Nominal Zero.
}

\author{
Estudo realizado para a Presidência da Federação das Indústrias do Estado do Paraná \\ pelo Grupo de Estudos de Macrodinâmica do Desenvolvimento do Departamento de \\ Economia da Universidade Federal do Paraná.
}

Site: www.economia.ufpr.br/pos/grupos

\author{
José Luis da Costa Oreiro \\ Marcelo Luiz Curado \\ Lucas Dezordi \\ Marcelo Passos
}

O argumento central da proposta do deputado federal Antônio Delfim Netto de déficit público nominal zero nos próximos três anos está na idéia de que o déficit nominal zero irá possibilitar uma redução da dívida pública em proporção do PIB para níveis satisfatórios. Esta medida ocasionaria uma queda imediata da taxa de juros real.

Existem fortes evidências empíricas que apontam para o valor excessivo do endividamento do setor publico no Brasil. Com efeito, a experiência internacional mostra que uma boa parte dos países emergentes que declararam default nos últimos 30 anos tinha uma dívida pública como proporção do PIB inferior a 40\%. As diferenças observadas na história de default entre os países desenvolvidos e os países emergentes parecem indicar que os últimos não podem sustentar uma dívida como proporção do PIB tão alta como às dos países desenvolvidos. Isso porque a estrutura fiscal dos países emergentes possui características peculiares, as quais limitam a capacidade destes países de sustentar uma dívida pública como proporção do PIB superior a 40\%. Entre essas características devemos destacar uma maior variabilidade das receitas tributárias em comparação com os paises desenvolvidos, o que faz com que os paises emergentes estejam sujeitos a uma perda maior de receita tributária em períodos de recessão do que os países desenvolvidos; um comprometimento maior das receitas do governo com o pagamento de juros nos países emergentes (na média 17\%) do que nos países desenvolvidos (na média 10\%); por fim, os paises emergentes possuem mais dificuldade para gerar superávits primários expressivos quando a divida publica como proporção do PIB ultrapasse o limite de 50\%. Essas razões indicam que países emergentes devem procurar manter uma dívida pública como proporção do PIB num patamar bem inferior ao prevalecente nos países desenvolvidos.

O endividamento brasileiro é excessivo, disso não temos dúvida, e a proposta de déficit nominal zero atuaria no sentido de reduzir a dependência do governo brasileiro com respeito ao "humor" dos agentes do mercado financeiro, na medida em que contribua para reduzir a divida como proporção do PIB para um patamar aceitável para paises emergentes. Essa redução aumentaria os graus de liberdade na condução da política macroeconômica, permitindo ao governo ignorar a maior parte das "sugestões" dos analistas do mercado financeiro. Por outro lado, a economia brasileira exibe o inglório título de possuidora da maior taxa real de juros do mundo. Em que medida a proposta de déficit nominal zero poderia contribuir para reduzir a taxa real de juros para patamares mais civilizados como, por exemplo, 5 a $6 \%$ real ao ano?

Argumenta-se que a proposta de déficit nominal zero atuaria no sentido de reduzir a taxa real de juros de equilíbrio da economia brasileira, conceito este que consiste na soma da taxa de juros internacional com o "prêmio de risco" país, dado o 
elevado grau de abertura da conta de capitais brasileira. O prêmio de risco país é medido pelo EMBI+ (Emerging Market Bond Index Plus) produzido pelo J.P.Morgan. Estudos empíricos têm mostrado que os governos de países com pior classificação de risco também pagam taxas de juros mais altas por seus títulos. Quanto pior a avaliação de um país pelas agências internacionais de classificação; maiores tendem a ser os juros de suas dívidas.

As agências internacionais avaliam o risco com base em um conjunto pequeno de indicadores (crescimento do PIB, taxa de inflação, dívida pública como proporção do PIB, grau de abertura comercial etc). De acordo com estudo recente realizado pelo Banco Mundial ${ }^{1}$, o volume da dívida pública em relação ao PIB é um indicador importante, mas não é o único que as agências levam em consideração para avaliar este risco. Dessa forma, pode-se afirmar que a proposta de déficit nominal zero contribuiria na redução do prêmio de risco-país e, portanto, para a queda da taxa real de juros de equilíbrio. Contudo, duas observações devem ser feitas. Em primeiro lugar, a queda do prêmio de risco-país - atualmente em 450 pontos base - será pequena a não ser que seja acompanhada pela melhoria em outras variáveis macroeconômicas como, por exemplo, o grau de abertura da economia, a redução da divida externa como proporção das exportações e etc. Em segundo lugar, o "dilema dos juros” no Brasil hoje não se explica por uma elevada taxa real de juros de equilibrio - nossas estimativas sobre o valor dessa taxa são de $6.5 \%$ ao ano ${ }^{2}$ - mas sim pela completa incapacidade do Banco Central do Brasil em fazer com que a taxa real de juros efetiva convirja para o valor de equilibrio dessa taxa. Com efeito, a taxa real de juros efetiva é atualmente superior a $13 \%$ ao ano, ou seja, quase $100 \%$ maior do que a taxa real de juros de equilíbrio!

A proposta de déficit nominal zero pode contribuir para acelerar a convergência da taxa de juros real efetiva para o seu valor de equilíbrio, desde que a mesma seja adotada no bojo de uma reformulação do atual regime de metas de inflação ${ }^{3}$. Nos países que adotam o regime de metas de inflação - como, por exemplo, a Nova Zelândia, Canadá, Reino Unido, Israel e etc - as metas inflacionárias são definidas com base no core inflation (núcleo de inflação), o que implica excluir do índice que baliza as metas inflacionárias aqueles produtos que estão sujeitos a "choques de oferta" como, por exemplo, energia e gêneros agrícolas. Dessa forma, se assegura que o Banco Central só irá aumentar a taxa de juros se houver pressão de demanda agregada, uma vez que elevações da taxa de juros são inócuas sobre a inflação causada por "choques de oferta".

Uma vez reformulado o regime de metas inflacionárias, a proposta de déficit nominal zero irá implementar uma verdadeira política fiscal contra-cíclica. Toda a vez que as pressões de demanda agregada obrigarem o Banco Central a engendrar um novo ciclo de aumentos da taxa básica de juros; o Ministério da Fazenda, comprometido com a meta de déficit nominal zero, terá que aumentar o superávit primário, gerando uma contração fiscal. $O$ efeito dessa contração fiscal sobre a demanda agregada irá fazer com que seja necessário um aumento menos pronunciado da taxa real de juros; contribuindo para manter a taxa real de câmbio em patamares competitivos, minimizando assim o impacto da política antiinflacionária sobre o saldo da balança

\footnotetext{
${ }^{1}$ Canuto, O; Fonseca dos Santos, P; Porto, P. (2004). "Macroeconomics and Sovereign Risk Ratings". World Bank Discussion Papers, Janeiro.

${ }^{2}$ Supondo uma taxa real de juros de $2 \%$ para a economia dos Estados Unidos, com base em estimativas do próprio Federal Reserve, e um prêmio de risco-país de 450 pontos base, ou seja, 4.5\%.

${ }^{3}$ Uma proposta completa de reformulação do regime de metas de inflação é feita por Mendonça, $\mathrm{H}$; Oreiro, J.L; Curado, M. (2005).’Uma Proposta de Ajuste no Regime de Metas de Inflação”. Valor Econômico, 06 de Julho.
} 
comercial e sobre os investimentos do setor privado. Em outras palavras, a proposta de déficit nominal zero é uma forma de se reduzir o papel da política monetária no combate a inflação; substituindo-se em parte o instrumento monetário por um uso mais intensivo da política fiscal.

Deve-se ressaltar a importância da reformulação do regime de metas inflacionárias em conjunto com a adoção da proposta de déficit nominal zero. A persistirem as deficiências do atual regime de metas de inflação brasileiro, não há nenhuma garantia de que a adoção da proposta de déficit nominal zero seja capaz de gerar uma queda acentuada da taxa real de juros efetiva. Nesse contexto, a contração fiscal exigida pela adoção da referida proposta - um corte dos gastos públicos da ordem de 3\% do PIB - irá gerar uma recessão sem precedentes na historia recente do Brasil; agravando ainda mais o já dramático quadro social brasileiro. 